\title{
Research Paper \\ Metabolic Effects of Methanol Extract of Harmal (Peganum Harmal ) in Rats Fed With Normal Diet
}

\author{
Esmail Mollashahi ${ }^{1}$, Hamid Reza Kazerani ${ }^{1 *}{ }^{*}$
}

1. Department of Basic Sciences, School of Veterinary Medicine, Ferdowsi University of Mashhad, Mashhad, Iran.

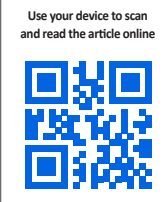

Ctraton Mollashahi E, Kazerani HZ. [Metabolic Effects of Methanol Extract of Harmal (Peganum harmal ) in Rats Fed With Normal Diet (Persian)]. Quarterly of "The Horizon of Medical Sciences". 2020; 26(4):414-431. https://doi.org/10.32598/ hms.26.4.2823.1

dol'https://doi.org/10.32598/hms.26.4.2823.1

Key words:

Peganum harmal Obesity, Food intake, Thyroid hormones

\section{A B STRACT}

Aims The research aimed to investigate the effects of harmal (Peganum harmal) seed extract on the weight and some metabolic parameters.

Methods \& Materials Male rats, in groups of 7, received different doses of the methanol extract of harmal seed $(100,200$, and $400 \mathrm{mg} / \mathrm{kg} / \mathrm{d}$ body weight) or placebo via a gastric tube for 42 days. At the end of the experiment, the weights of the body, liver, spleen, and heart, and also the levels of some serum parameters, including glucose, cholesterol, triglyceride, low-density lipoprotein, high-density lipoprotein, insulin, growth hormone, and thyroid hormones, as well as the composition of the carcass were investigated.

Findings The mean weight gain, food intake, and the serum level of triiodothyronine (T3) significantly declined in the rats receiving the extract at $400 \mathrm{mg} / \mathrm{kg}$. In contrast, the serum level of cholesterol in the group increased $(\mathrm{P}<0.001)$. The serum levels of glucose were significantly lower in all experimental groups compared to the control. Furthermore, the groups treated with the methanol extract dose-dependently showed higher serum lactate dehydrogenase levels compared to the control $(P<0.05)$. No significant differences were observed regarding other studied parameters compared with the control group.

Conclusion This research suggests positive effects for harmal extract on some metabolic parameters and weight. At least one of the involved mechanisms seems to be declined appetite and hence decreased feed intake.

\section{English Version}

\section{Introduction}

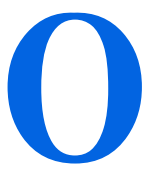

besity is the most important nutritional disease in developed and developing countries, which its prevalence is increasing rapidly. According to the World Health Organization (WHO), the body mass index (weight in kilograms divided by height squared in meters) of above 25 is considered as overweight and above 30 as obesity. According to the WHO report in 2016, more than 1.9 billion people over the age of 18 were overweight, of which 650 million were obese. The prevalence of obesity among children is also increasing; currently, 41 million children under the age of five are obese.

Obesity is involved in many diseases, including diabetes type II, cardiovascular disease, hypertension, metabolic

\section{* Corresponding Author:}

Hamid Reza Kazerani, PhD.

Address: Department of Basic Sciences, School of Veterinary Medicine, Ferdowsi University of Mashhad, Mashhad, Iran.

Tel: +98 (51) 38763852

E-mail: kazerani@um.ac.ir 
syndrome, asthma, digestive disorders, skeletal problems, and even some types of cancer [2]. Hence, in this field, a lot of research is being done worldwide.

Harmal, scientifically named Peganum harmal, is a plant of the Zygophyllaceae family. It is herbaceous and perennial, with a height of 30 to $40 \mathrm{~cm}$, and is mostly grown as a wildflower in the barren lands of North Africa, the Mediterranean region, Turkey, Syria, and Iran [3-6]. Harmal contains the alkaloids of harmaline, harmine, harmalol, harman, and paganine. This plant also contains volatile essential oil, tannins, and a glycoside flavonoid called rutoside [7].

In ancient Arab medication, harmal seed has been used as a sedative, diaphoretic, anti-worm, and causing menstruation $[4,6,7]$. Harmal seeds have also been shown to have anti-flatulence, milk-enhancing, body-warming, colic-relieving, jaundice, sciatica, insanity, Alzheimer disease and to be effective against $[3,5]$. Harmal seed was known as a drug and has been prescribed as a fever reliever and stomach pain reliever [3]. According to new scientific research, it has anti-pest, anti-microbial, anti-parasitic, anti-cancer, anti-inflammatory, anti-seizure, and analgesic effects. Besides, Its cardiovascular, teratogenicity, and antioxidant properties of harmal have been proved. In traditional medicine, it was also used for weight loss.

Since, according to the scientific methodology, sufficient information about the effects of this herb on weight and serum parameters is not available, this study investigated the effect of its different doses of the methanolic extract on weight and some metabolic parameters in rats.

\section{Materials and Methods}

In this study, 28 male Wistar rats weighing $220 \pm 60 \mathrm{~g}$ were used. The rats were kept in the veterinary clinic of Ferdowsi University of Mashhad, Mashhad City, Iran in the condition of 12 hours of light and 12 hours of darkness and an ambient temperature of $20^{\circ} \mathrm{C}-24^{\circ} \mathrm{C}$. The animals had free access to drinking water during the experiment. Four days before the experiment and throughout the experiment, the rats were fed in separate cages (individually) with a normal diet (Khorasan Javaneh Company, Mashhad) (Table 1).

\section{Experimental groups}

The rats were randomly divided into 4 groups. The groups of 1 to 3 received 100, 200, or $400 \mathrm{mg}$ of harmal methanolic extract per $\mathrm{kg}$ of body weight daily for 6 weeks, depending on dry matter weight. Group 4, as the control group, received only a placebo.

\section{Studied parameters}

Calculation of food intake and weight gain was performed every 7 days after starting of treatment in all rats. Also, the liver, spleen, and heart weights were assessed at the end of the experimental period. After about 10 hours of not feeding, the blood samples were taken from all rats on day 42 under anesthesia (sodium thiopental: $60 \mathrm{mg} / \mathrm{kg}$ ). To separate the serum, blood samples were centrifuged at 3000 rpm for 20 minutes after coagulation. The feed conversion ratio in the studied animals was calculated based on the following formula [8]:

$$
\text { Feed conversion ratio }=\frac{\text { Dietary intake in grams }}{\text { Increased body weight in grams }}
$$

Table 1. Animal dietary nutrient composition based on the manufacturer's brochure

\begin{tabular}{ccc}
\hline Combination & Value \\
\hline Energy & $\mathrm{kcal} / \mathrm{kg} 2750$ & $21 \%$ \\
\hline Protein & $5.6 \%-7 \%$ & $5.5 \%$ \\
\hline Fat & $0.0 .5 \%$ \\
\hline Raw fiber & $0.0 .5 \%$ \\
\hline Methionine & $0.5 \%$ \\
\hline Lysine & $1.5-2.5$ \\
\hline Salt & Ouarterly of \\
Calcium to phosphorus ratio & The Horizon of Medical Sciences
\end{tabular}


The amount of total fat in the samples was determined using the Nafikov-Atkinson method [9]. In this experiment, fats are dissolved in chloroform and other substances are either dissolved in water and alcohol or deposited by centrifugation and then removed.

To measure muscle protein, the sample was placed in liquid nitrogen 3 times (15 minutes each) at 30-minute intervals. The sample was mixed with $10 \mathrm{~mL}$ of $0.05 \mathrm{M}$ potassium phosphate buffer ( $\mathrm{pH} 7.5$ with $0.55 \mathrm{M}$ potassium iodide). After centrifugation (20 minutes, $3000 \mathrm{rpm}$ ) of high solution (containing protein), muscle protein was measured by Biore Method (Pars Azmoun Kit, Iran). The percentage of dry matter of muscle was evaluated by the following formula [10]

\section{(weight of sample and plate before placing in the oven)- (weight of sample and plate after placing in the oven)

$$
\text { Humidity percentage }=\frac{\text { Sample weight }}{} \times 100
$$ \\ Percentage of dry matter $=100-$ Humidity percentage}

The percentage of muscle ash was evaluated as follows [10]:

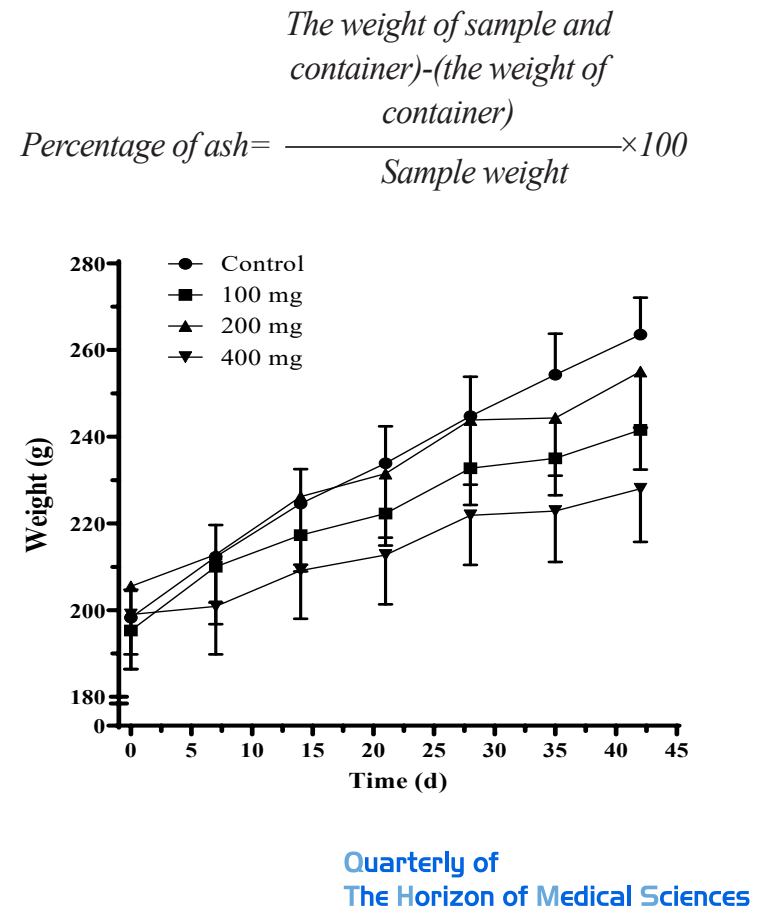

Figure 1. Weight of the animals studied in different experimental groups; The experimental groups received placebo (control) or different doses of methanolic extract of pecan seed through a gastric tube for 42 days. Data are expressed as the mean \pm standard error of the mean (Mean \pm SEM).
The glucose (Pars test kit, Iran), cholesterol, triglyceride (Biosystem commercial kits, Spain), and high-density lipoprotein and low-density lipoprotein of serum (Pishtaz Teb commercial kit, Iran) were measured by Autoanalyzer (BT-3000, Italy) with a calorimetric method. The hormones of insulin (DLS-1600 kit, Diasorin, Italy), growth (GH kit, Diasorin, Italy), triiodothyronine (T3), and thyroxine (T4) (Radim commercial kits, Italy) were measured with chemiluminescence method (RAD-120, Italy). Total serum protein was also measured with the Biore method (Pars Azmoun Kit, Iran).

\section{Data analysis}

Statistical calculations and the figures were performed by GraphPad Prism software (GraphPad Prism V. 5.0, GraphPad Software, USA). The normal distribution of data was checked and confirmed by the Shapiro-Wilk test and the Kolmogorov-Smirnov test. The data are expressed as Mean \pm standard error of the mean (Mean \pm SEM). Statistical comparison between different experimental groups was performed by analysis of variance (ANOVA) and Dant supplementary test. In all cases, the difference was considered significant at $\mathrm{P}<0.05$.

\section{Results}

The mean body weight at the end of the 42-day experimental period was higher in the control group than the ex-

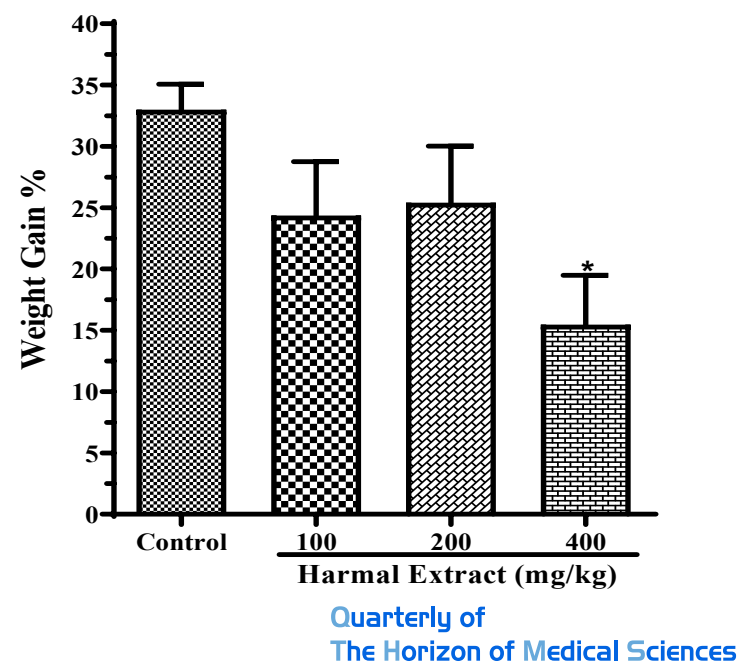

Figure 2. Weight of animals studied in different experimental groups; The experimental groups received placebo (control) or different doses of methanolic extract of pecan seed through a gastric tube for 42 days. Data are expressed as the mean \pm standard error of the mean (Mean \pm SEM). The asterisk indicates a significant difference compared to the control group $(\mathrm{P}<0.05)$. 


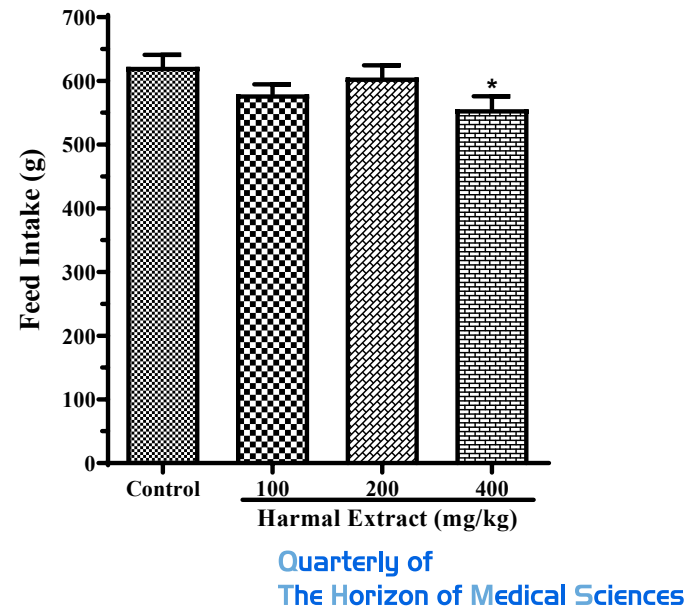

Figure 3. Rat food consumption in different experimental groups; The experimental groups received placebo (control) or different doses of methanolic extract of pecan seed through a gastric tube for 42 days. Data are expressed as the mean \pm standard error of the error (Mean \pm SEM). The asterisk indicates a significant difference compared with the control group $(\mathrm{P}<0.05)$.

perimental groups (Figure 1). The mean body weight in the group received the highest dose of harmal extract was lower than the other groups. However, the differences between different experimental groups were not statistically significant.

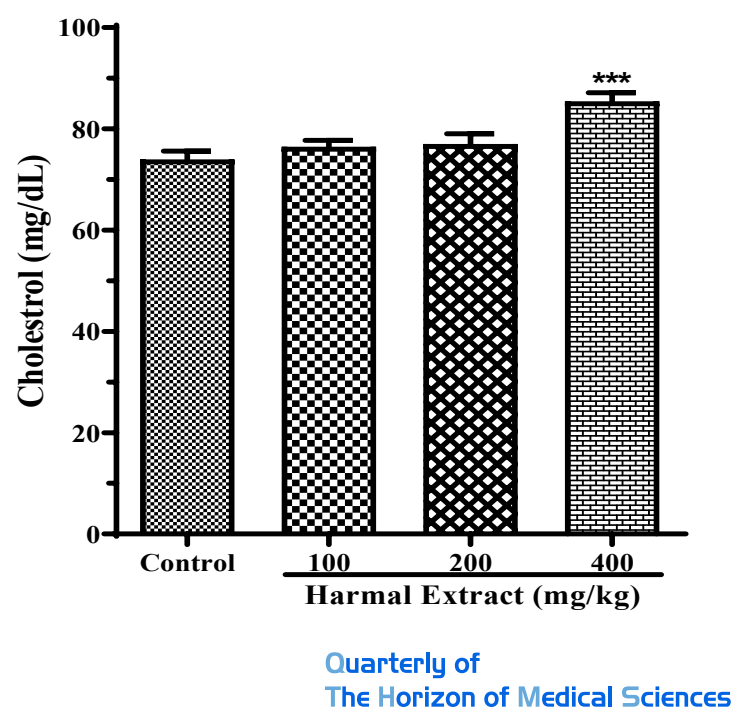

Figure 5. Blood serum cholesterol of rats in different experimental groups; The experimental groups received placebo (control) or different doses of methanolic extract of pecan seed through a gastric tube for 42 days. Data are expressed as the mean \pm standard error of the mean (Mean \pm SEM). The asterisk indicates a significant difference compared with the control group $(\mathrm{P}<0.01)$.

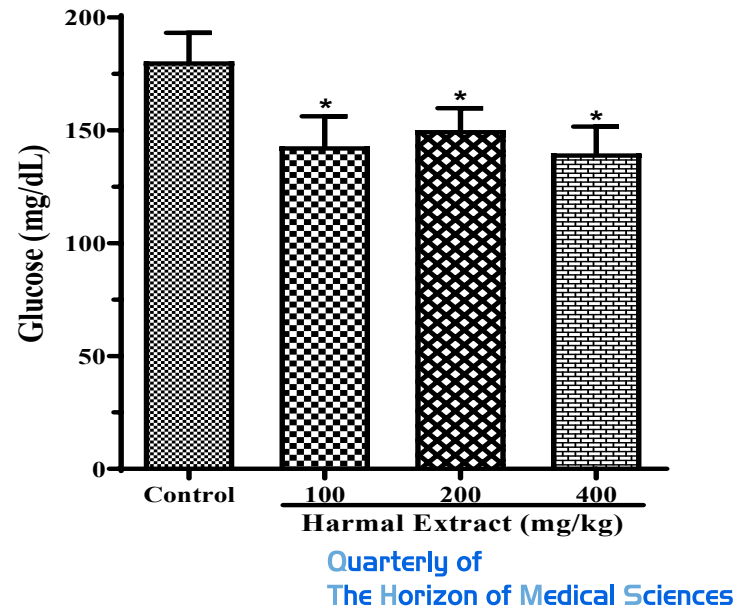

Figure 4. Blood serum glucose of animals in different experimental groups; The experimental groups received placebo (control) or different doses of methanolic extract of pecan seed through a gastric tube for 42 days. Data are expressed as mean \pm standard error of the mean (Mean \pm SEM).

The mean weight gain concerning baseline weight at the end of the 42-day of the experimental period was 33\% in the control group (Figure 2). The percentage of body weight gain in the experimental groups was lower than the control group. The lowest mean was observed in the group of $400 \mathrm{mg} / \mathrm{kg}$ of extracts $(15.5 \%, \mathrm{P}<0.05)$. The average

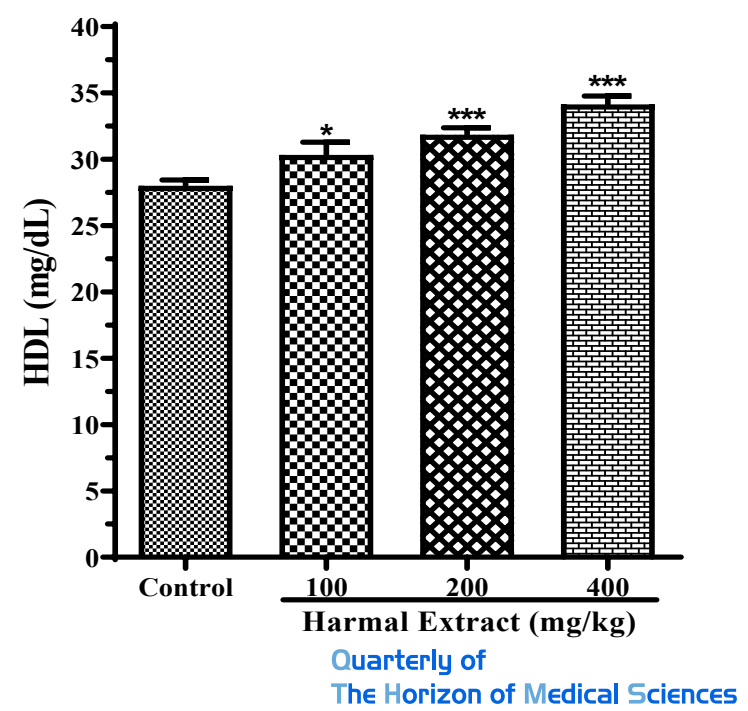

Figure 6. Blood high-density lipoprotein of the serum of the rats in different experimental groups; The experimental groups received placebo (control) or different doses of methanolic extract of pecan seed through a gastric tube for 42 days. Data are expressed as the mean and standard error of the mean (SEM). The asterisk indicates a significant difference compared with the control group $(* \mathrm{P}<0.05$, $* * * \mathrm{P}<0.001)$. 
food intake in this group was significantly lower than the control group (Figure 3); however, the mean feed conversion ratio did not differ between groups (Table 2).

Muscle characteristics such as fat percentage, protein, ash, and dry matter did not show significant differences between the experimental groups (Table 2). The percentage of body weight of internal organs, including the liver, spleen, and heart did not differ significantly between different groups (Table 2). The serum glucose level in the treatment groups was significantly lower than the control group (Figure 4). However, cholesterol and serum levels of high-density lipoprotein were higher in the treatment groups (Figures 5, 6). Other serum parameters, including triglyceride, lactate dehydrogenase, and total protein did not show significant differences between the experimental groups (Table 2).

Among the measured hormones, T3 was significantly lower in the treatment groups at doses of 200 and $400 \mathrm{mg}$ / $\mathrm{kg}$ body weight than the control group (Figure 7). Other studied hormones, including T4, growth hormone, and insulin did not show significant differences (Table 2).

\section{Discussion}

Obesity is a nutritional disease that is involved in many cardiovascular, liver, joint abrasions, diabetes, and cancer diseases [11, 12]. Around $60 \%$ of people over the age of 20 in Iran are overweight and obese. Also, 12\%-18\% of Iranian adolescents are overweight and $6.5 \%$ of them are considered obese. Treatment of obesity reduces mortality from diabetes by $92 \%$, cancer by $60 \%$, coronary artery disease by $56 \%$, and surgical death by $40 \%$ [12].

This study investigated the effect of harmal seeds on the weight and food intake in rats. Also, a series of serum biochemical parameters were primarily investigated the possible mechanisms involved. The animals that received harmal methanolic extract at a dose of $400 \mathrm{mg} / \mathrm{kg}$ showed less weight than the control group. In this regard, in another study, a significant weight loss has been reported in broilers as a result of consuming this plant [13]. In another study, however, the methanolic extract of harmal seeds at 200 and $250 \mathrm{mg}$ per liter of drinking water increased the weight of broilers. Increasing the dose to $300 \mathrm{mg} / \mathrm{L}$, however, caused

Table 2. Parameters studied in different experimental groups

\begin{tabular}{|c|c|c|c|c|}
\hline \multirow{3}{*}{ Groups } & \multirow{3}{*}{ Control } & \multicolumn{3}{|c|}{ Mean \pm SD } \\
\hline & & \multicolumn{3}{|c|}{ Harmal Seed Extract (mg/kg) } \\
\hline & & 100 & 200 & 400 \\
\hline Food conversion ratio & $19.4 \pm 1.4$ & $30.8 \pm 7.3$ & $29.3 \pm 6.1$ & $32.8 \pm 5.6$ \\
\hline Muscle fat (\%) & $7.1 \pm 0.7$ & $6.8 \pm 0.5$ & $6.1 \pm 0.8$ & $5.8 \pm 0.6$ \\
\hline Muscle protein (\%) & $15.2 \pm 1.3$ & $14.2 \pm 1.7$ & $13.2 \pm 1.5$ & $12.9 \pm 0.3$ \\
\hline Muscle ash (\%) & $1.86 \pm 0.37$ & $1.45 \pm 0.12$ & $1.66 \pm 0.21$ & $1.51 \pm 0.21$ \\
\hline Muscle dry matter (\%) & $33.3 \pm 0.7$ & $31.2 \pm 0.6$ & $31.4 \pm 1.1$ & $30.8 \pm 0.5$ \\
\hline Liver weight (\%) & $3.37 \pm 0.10$ & $3.45 \pm 0.09$ & $3.41 \pm 0.07$ & $3.53 \pm 0.07$ \\
\hline Spleen weight (\%) & $0.29 \pm 0.01$ & $0.31 \pm 0.02$ & $0.31 \pm 0.02$ & $0.30 \pm 0.02$ \\
\hline Heart weight (\%) & $0.36 \pm 0.01$ & $0.40 \pm 0.03$ & $0.31 \pm 0.05$ & $0.38 \pm 0.01$ \\
\hline Triglycerides (mg/dL) & $52.3 \pm 1.1$ & $53.5 \pm 2.9$ & $53.4 \pm 2.5$ & $51.3 \pm 1.7$ \\
\hline $\mathrm{LDL}(\mathrm{mg} / \mathrm{dL})$ & $8.6 \pm 0.6$ & $8.0 \pm 0.4$ & $7.7 \pm 0.6$ & $8.0 \pm 0.5$ \\
\hline Total protein (g/dL) & $6.4 \pm 0.1$ & $6.7 \pm 0.2$ & $6.5 \pm 0.2$ & $6.7 \pm 0.2$ \\
\hline $\mathrm{T} 4(\mu \mathrm{g} / \mathrm{dL})$ & $2.3 \pm 0.2$ & $2.2 \pm 0.4$ & $2.2 \pm 0.2$ & $0.2 \pm 0.1$ \\
\hline Growth hormone (ng/ml) & $0.10 \pm 0.02$ & $0.08 \pm 0.00$ & $0.08 \pm 0.01$ & $0.08 \pm 0.01$ \\
\hline Insulin ( $\mu \mathrm{U} / \mathrm{ml})$ & $0.09 \pm 0.00$ & $0.10 \pm 0.00$ & $0.09 \pm 0.00$ & $0.09 \pm 0.00$ \\
\hline
\end{tabular}




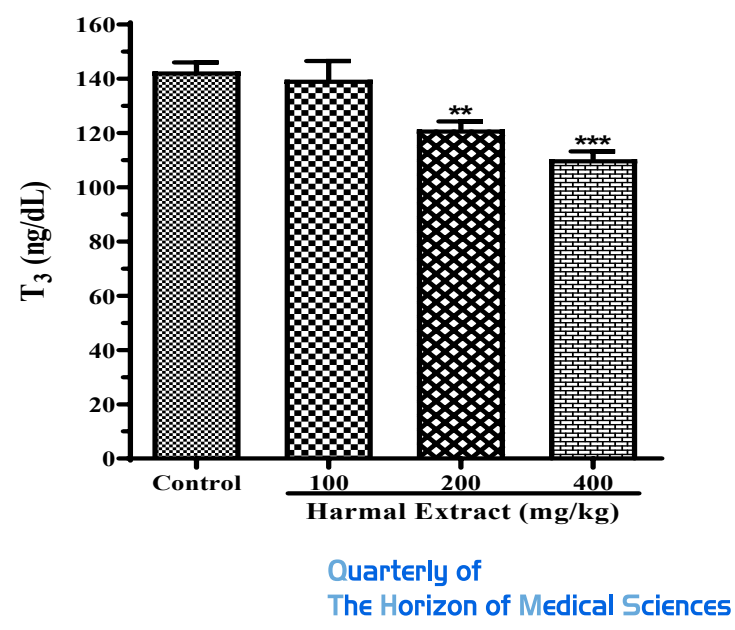

Figure 7. Serum T3 of animal blood in different experimental groups

The experimental groups received placebo (control) or different doses of methanolic extract of pecan seed through a gastric tube for 42 days. Data are expressed as the mean and standard error of the mean (SEM). The asterisk indicates a significant difference compared with the control group $(* \mathrm{P}<0.01, * * * \mathrm{P}<0.01)$.

a significant decrease in this variable compared with the control group [14].

In other studies, ethanolic and chloroform extracts of harmal have been reported to increase rat weight [15]. Harmine, one of the alkaloids in harmal seeds, does not affect the weight of diabetic rats [16], but 4-hydroxy pipecolic acid has reduced the weight of rats [17]. Based on this finding, perhaps the weight loss effect of harmal in the present study could be attributed to this substance.

On the other hand, in the present study, harmal methanolic extract at a dose of $400 \mathrm{mg} / \mathrm{kg}$ reduced food intake; however, in a study on broiler chickens, it did not affect chicken food intake [14]. Harmine also did not affect the amount of food consumed by diabetic rats [16]. The observed differences may be due to differences in the species under study. Considering the correlation between reduced food intake and overweight, it seems that at least one of the weight loss factors in treated rats can be considered as decreased appetite.

The feed conversion ratio was higher in the groups that received different doses of methanolic extract than the control group, but these differences were not significant. In a study performed on broiler chickens, methanolic extract of harmal seed improved feed conversion ratio [14]. Similar results have been reported with harmal seeds [13], broilers seem to show different effects on receiving a methanolic extract of harmal seed compared to rats.

In the present study, some serum parameters related to weight and appetite were also examined. Glucose levels decreased in rats that received different doses of harmal methanolic extract compared with the control group; however, no significant change was observed in the serum insulin hormone levels of the animals. But, studies by other researchers have shown that ethanolic extract of harmal seed significantly reduced blood glucose levels in the healthy and diabetic rats [18].

The 4-hydroxy pipecolic acid stimulates glucose uptake in muscle cells and reduces fasting serum glucose levels in diabetic rats. Besides, it improves glucose tolerance. It also lowers plasma insulin hormone levels and improves insulin sensitivity by increasing its ability to lower blood sugar [17]. It has been suggested that 4-hydroxy pipecolic acid causes the transfer of GLUT- 4 from the inside to the surface of skeletal muscle cells and thus increases glucose consumption [19].

Harmine has also been shown to improve glucose metabolism in diabetic rats by increasing the expression of the PPAR $\gamma$ gene involved in adipogenesis. The metabolic effects of harmine are partly due to the inhibition of the betacatenin molecule ( $\beta$ catenin) involved in the WNT signal pathway (inhibitor of differentiation and expression of the PPAR $\gamma$ gene) [16].

Since the serum levels of triglyceride are directly related to obesity [20], the effect of different doses of harmal methanolic extract on this parameter was also studied in the present study, and no significant change in the serum levels of triglyceride was observed in rats.

According to the results of a study, 4-hydroxy pipecolic acid significantly reduced the serum triglyceride concentration of the rats [17]. Harmine also reduced the serum levels of triglyceride in diabetic rats [16]. Given that the two compounds existing in the seeds of harmal separately reduced the triglyceride concentration, it is possible that other compounds existing in the seeds of this plant, due to their inhibitory or interfering role, neutralized the reducing effects of triglycerides in the current study.

Because of the correlation between serum cholesterol level with body metabolism and obesity [16], this serum parameter was also investigated in the present study. In this study, the amount of serum cholesterol in the group that received the highest dose ( $400 \mathrm{mg} / \mathrm{kg}$ of extract) was significantly higher than the control group [21]. Also, 4-hydroxy 
pipecolic acid (extracted from the seeds of harmal ) has reduced cholesterol concentration in the rats [17].

Differences in the studied species may cause differences in the observed results. This event may also be attributed to an increase in high-density lipoprotein and no change in low-density lipoprotein. In the present study, harmal methanolic extract had no effect on serum low-density lipoprotein levels in rats; however, 4-hydroxy pipecolic acid isolated from harmal seeds reduced low-density lipoprotein levels in rats [17]. Differences in results may be related to other compounds in harmal seeds.

In this study, serum high-density lipoprotein levels were significantly and dose-dependently increased in the groups that received harmal methanolic extract. Similar results were observed with 4-hydroxy pipecolic acid increasing the serum high-density lipoprotein concentration of Wistar rats [17]. Therefore, perhaps the enhancing effect of serum high-density lipoprotein in harmal seeds can be attributed to 4-hydroxypipecolic acid. Proteins, like carbohydrates and fatty acids, play a role in the body's metabolism and energy supply [22].

In the present study, the methanolic extract of harmal seed had no effect on serum total protein concentration. In another study, harmal leaves reduced total serum protein in chickens [21]. However, no similar study was performed on the effect of methanolic extract of harmal seed on serum protein.

Thyroid hormones increase energy consumption and weight loss by increasing metabolism; however, T3 is more active than T4 [22]. In this study, harmal extract significantly reduced $\mathrm{T} 3$ but had no effect on serum T4 levels. In another study, pecan seed extract reduced plasma levels of the hormones $\mathrm{T} 3$ and $\mathrm{T} 4$ in rats [23].

Harmaline (one of the alkaloids in harmal seed extract) has inhibitory properties for the enzyme monoamine oxidase. On the other hand, if this enzyme is inhibited, the levels of catecholamine neurotransmitters (dopamine, norepinephrine, and epinephrine) and indoleamine (serotonin) increase. Because serotonin is a neurotransmitter that inhibits the secretion of thyrotropin-releasing hormone, inhibition of this enzyme can reduce the level of thyroid-stimulating hormone in plasma, followed by a decrease in T3 and T4 [24]. It seems that the weight loss observed in this study is not only due to the increase in thyroid hormones, but also these hormones decreased due to the consumption of harmal extract.
Growth hormone stimulates the growth of various tissues in the body, especially the growth of bones. It also increases metabolism by $15 \%-20 \%$ [22]. Growth hormone levels are lower in obese people [25]. There was no scientific report on the effect of this herb on plasma growth hormone levels. According to the present study, no change in serum growth hormone levels was observed.

In the present study, the mean percentage of heart weight was examined; there was no change in the mean heart weight of the rats. Also, the mean weight percentages of liver and spleen in rats that received different doses of methanolic extract of harmal were not different from the control group. No similar research was conducted on the effect of this herb on the percentages of heart, liver, and spleen weight.

\section{Conclusions}

In the present study, the effect of different doses of methanolic extract of harmal seed for 42 days on weight, appetite, and some serum parameters of growing rats was investigated. The methanolic extract significantly prevented the overweight of the studied animals. This effect was not associated with the changes in insulin and growth hormone. On the other hand, T3 hormone was not only not increased but also significantly decreased in rats treated with the extract. Since food intake in treated rats was significantly reduced, it seems that the methanolic extract of harmal seed, at least as one of the mechanisms involved, prevents weight gain in rats by reducing appetite.

\section{Ethical Considerations}

\section{Compliance with ethical guidelines}

This research has been done according to the rules and regulations of the Ethics Committee of Ferdowsi University of Mashhad. The bioethics and animal rights of the studied animals have been considered (Ethics Code: IR.UM. REC.1398.117).

\section{Funding}

This study was conducted with the financial support of the Vice Chancellor for Research, Ferdowsi University of Mashhad (Research No. 20071/3).

\section{Authors' contributions}

Conceptualization, Funding acquisition, Resources, Supervision: Hamid Reza Kazerani; Methodology, Investigation, 
Writing - original draft, Writing - review \& editing: Both authors.

Conflicts of interest

The authors declared no conflict of interest.

Acknowledgements

Hereby we thank the Vice Chancellor for Research of Ferdowsi University of Mashhad (20071/3). 
This Page Intentionally Left Blank 


\title{
اثرات متابوليك عصاره متانولى اسيند در رتهاى تغذيهشده با رزيم غذايى معمولى
}

(1) ' اسماعيل ملاشاهى'، "حميدرضا كازرانى

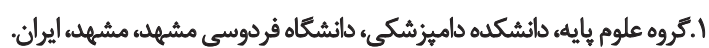

\begin{abstract}
حكنי

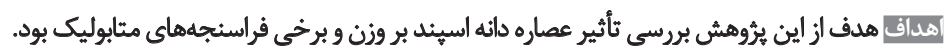

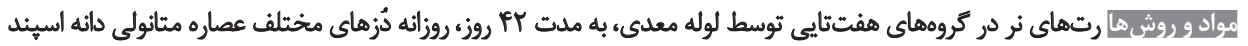

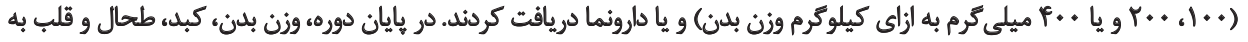

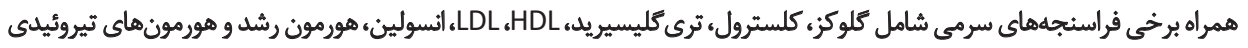

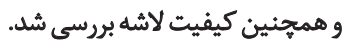

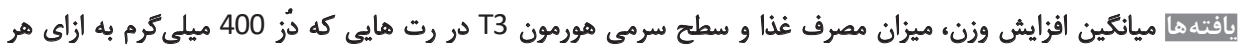

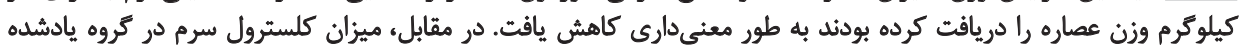

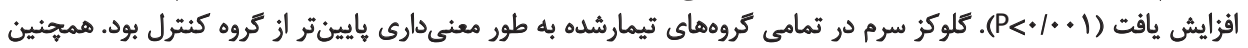

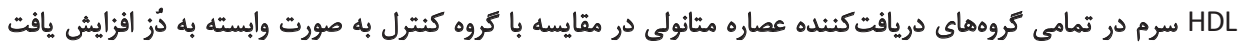

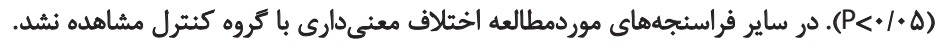

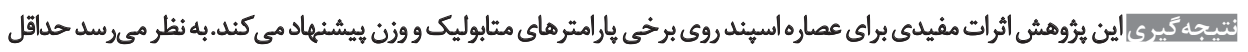

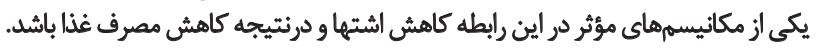

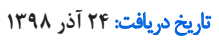

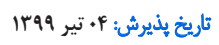

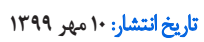

كليدوأثهها:

اسينلد، جاقيى، مصرف

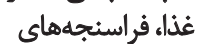
تسرمى، هورمون فرائيداي تيروئيدي سي

اسيند با نام علمى Peganum harmal إهياهي است از خانواده Fygophyllaceae مقدمd

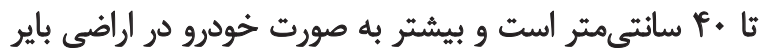

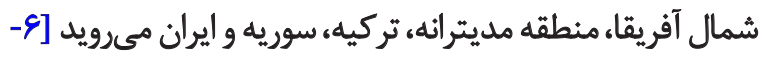

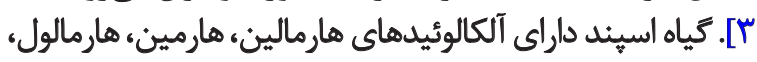

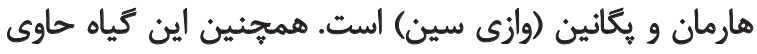

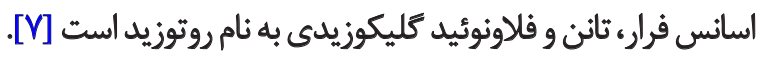

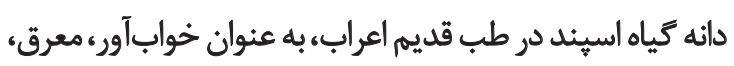

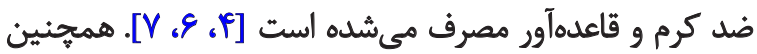

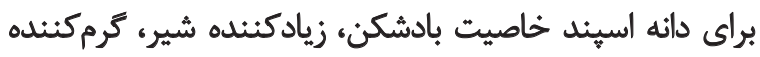

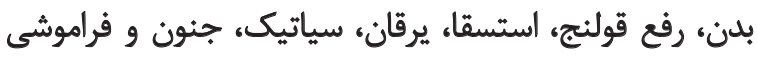

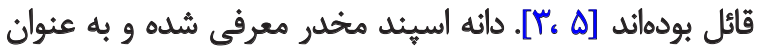

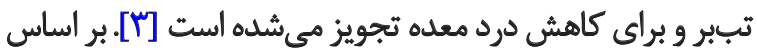

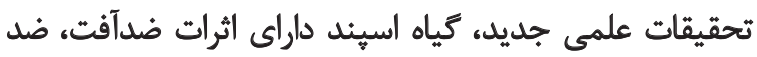

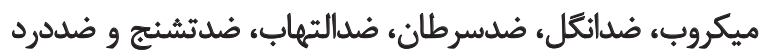

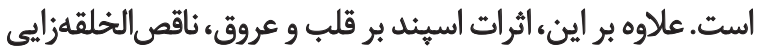

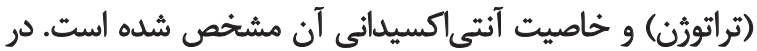

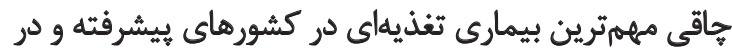

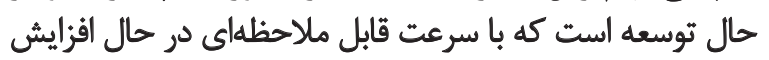

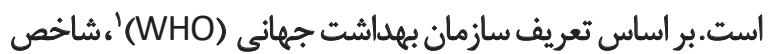

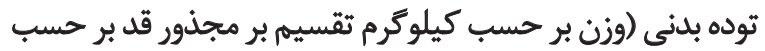

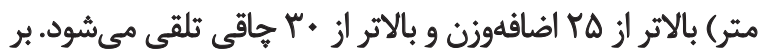

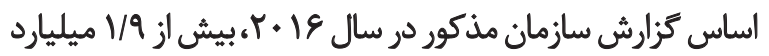

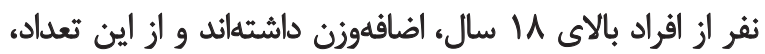

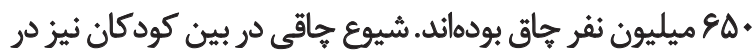

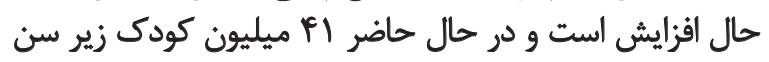

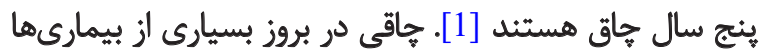

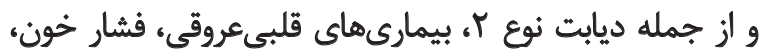

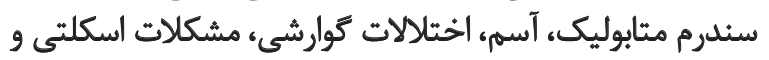

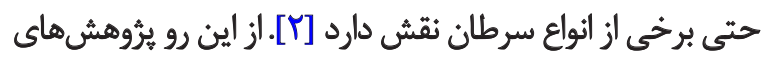
زيادى در سطح دنيا در اين زمينه در حال نقان انجام است.

1. World Health Organization

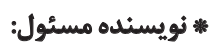

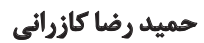

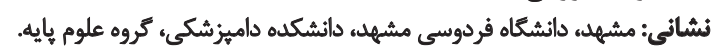
تلفن: يست الكترونيكي: kazerani@um.ac.ir 
جدول ا. تركيب مواد مغذى جيره حيوانات بر اساس بروشور شركت توليدكثنده

\begin{tabular}{|c|c|}
\hline مقدار & تركيب \\
\hline TVA Sيلوكالرى بر كيلوكرم . & أترأى \\
\hline r & يروتئين \\
\hline $8 / 0-\gamma$ & جرئ \\
\hline$\Delta / \Delta$ & فيبر خام \\
\hline .1 .0 & متيوئين \\
\hline$\cdot 1 \cdot \Delta$ & ليزين \\
\hline .10 & 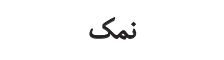 \\
\hline $1 / \Delta-Y / \Delta$ & نسبت كلسيم به فسفر \\
\hline
\end{tabular}

و قلب نيز در هايان دوره آزمايش مورد بررسى قرار كرفت. يس از

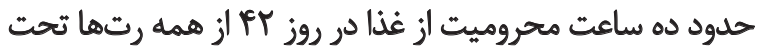

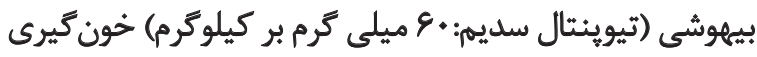

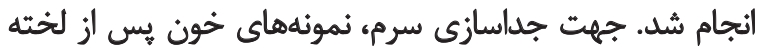

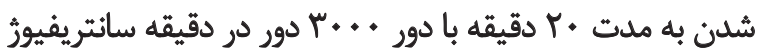
شند.

ضريب تبديل غذايى در حيوانات موردمطالعه بر اساس فرمول

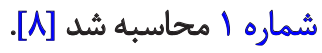

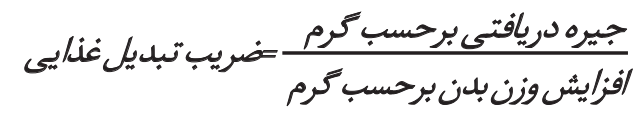

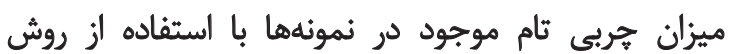
Nafikov-Atkinson

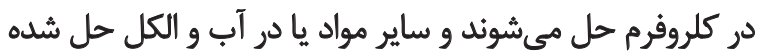

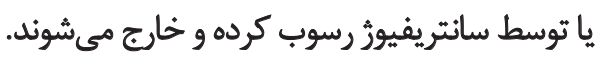

جهت سنجش يروتئين عضله، نمونه سه نوبت (هر بار 10

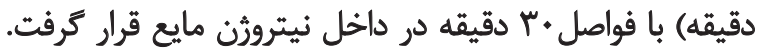

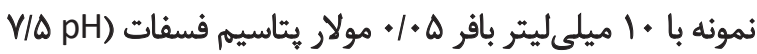

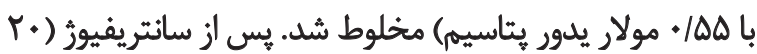

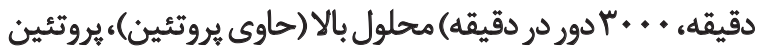

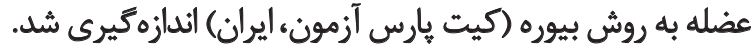
درصد ماده خشك عضله توسط فرمول شماره Y محاسبه شد

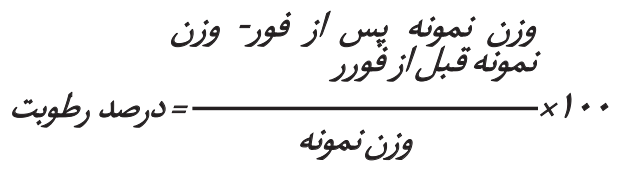

طب سنتى، اسيند رابه منظور لاغرى مورد استفاده قرار مى دادند.

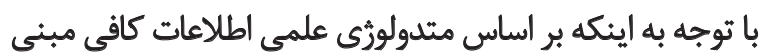

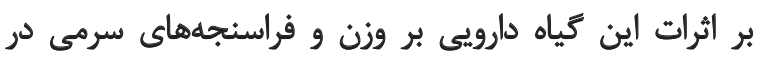

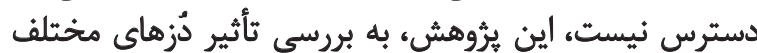

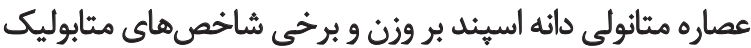

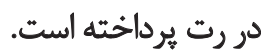

مواد وروشها نها

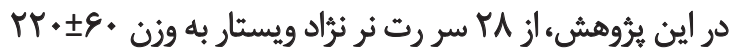

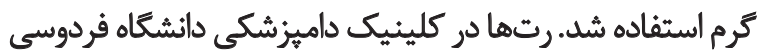

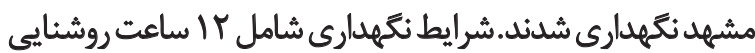

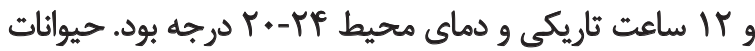

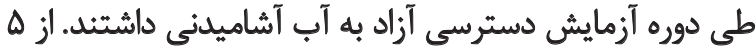

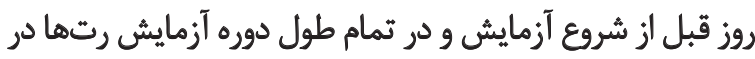

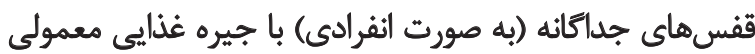

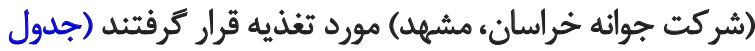

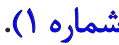

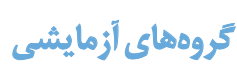

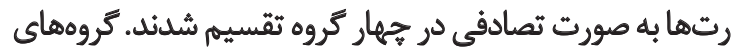

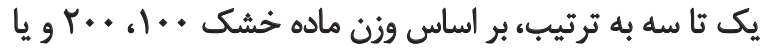

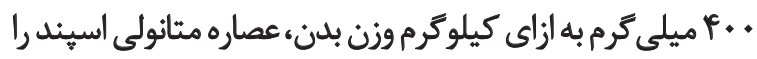

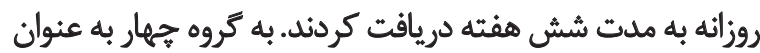
كروه كنترل، فقط دارونما خورانده شد.

\section{فراسئجه هاي موردمطالعه}

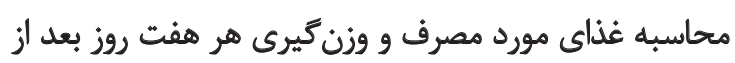

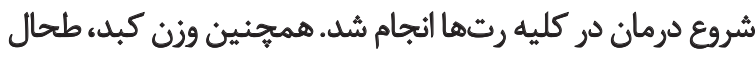


Latọ ميانكين وزن بلن در هايان دوره بأروزه آزمايش در كروه

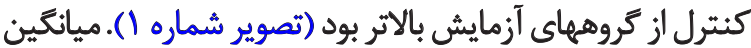

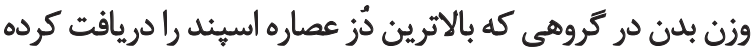

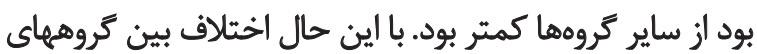

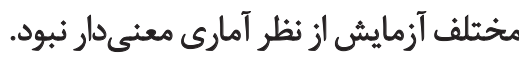
ميانكين افزايش وزن بدن نسبت به وزن اوليه در بايان دوره

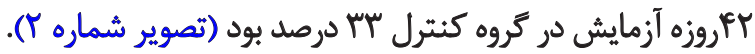

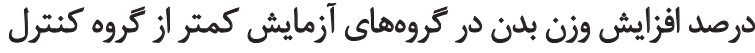

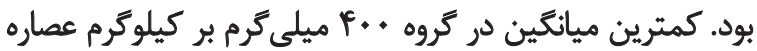

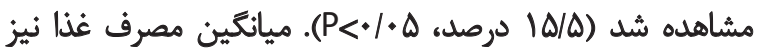

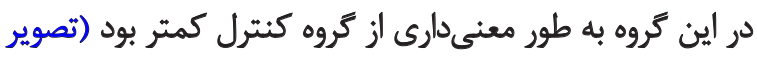

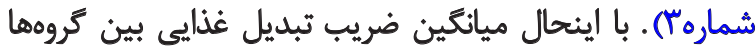
تفاوت نداشت (جدول شماره r).

ويرُّكى هاي عضله نظير درصد جربي، هروتئين، خاكستر و ماده

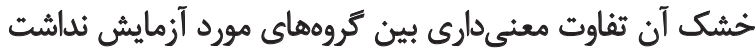

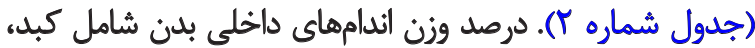

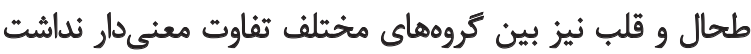

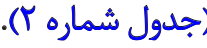

ميزان گلوكز سرم در گروههاى تيمار به طور معنى دارى از گروه

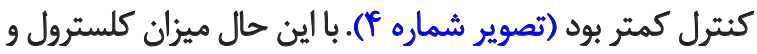

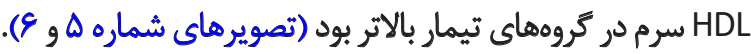

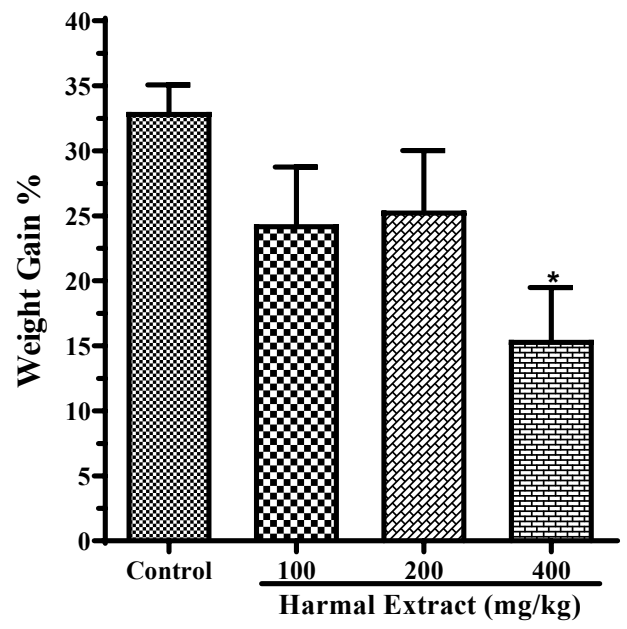

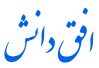

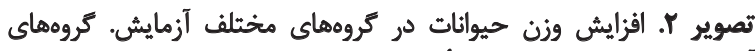

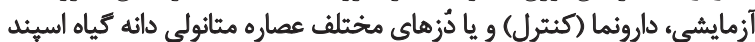

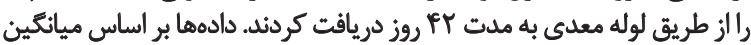

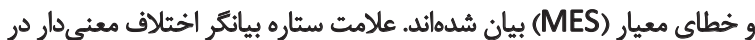

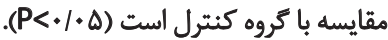

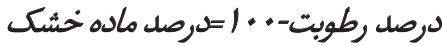

درصد خاكستر عضله با فرمول شماره ب زير محاسبه شد [ [1].

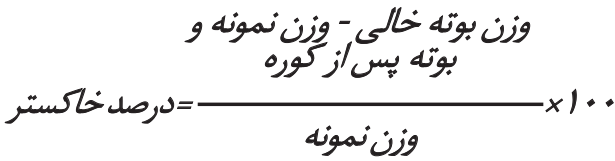

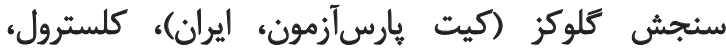

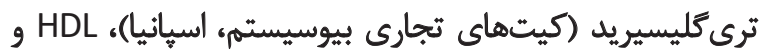

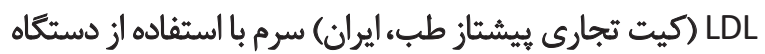

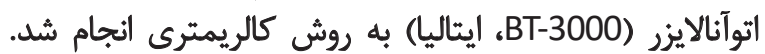

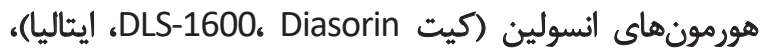

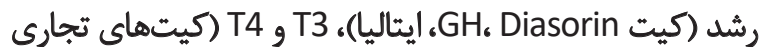

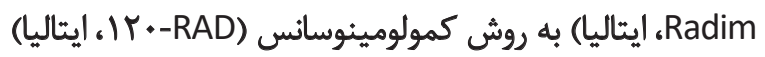

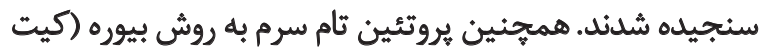
يارس آزمون، ايران) اندازهيرى شمين شد.

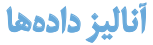

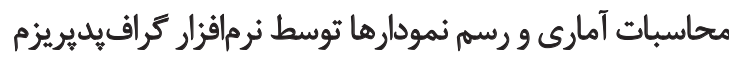
(GraphPad Software, USA ,GraphPad Prism VD/•) أنجام شد. توزيع ثرمال دادهها توسط آزمون شاييرو ويلك و

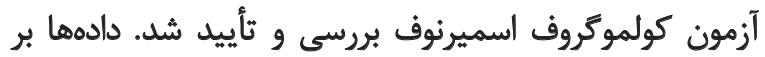

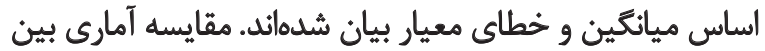

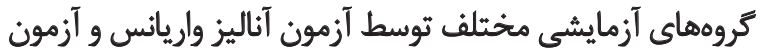

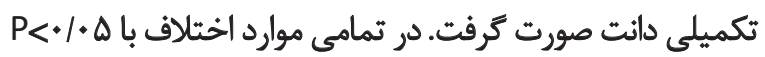
معنى دار تلقي شد.

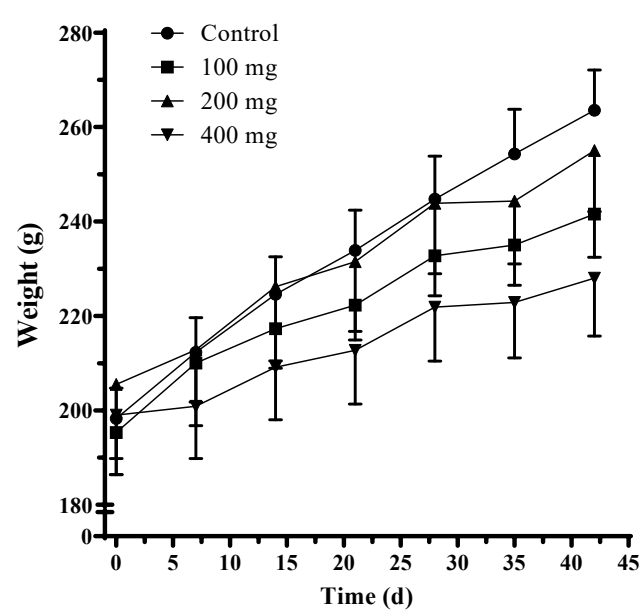

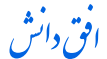

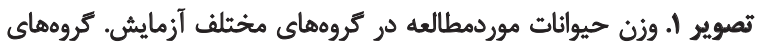

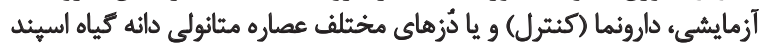

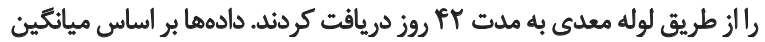
وخطاى معيار (SEM) بيان شدهاند. 


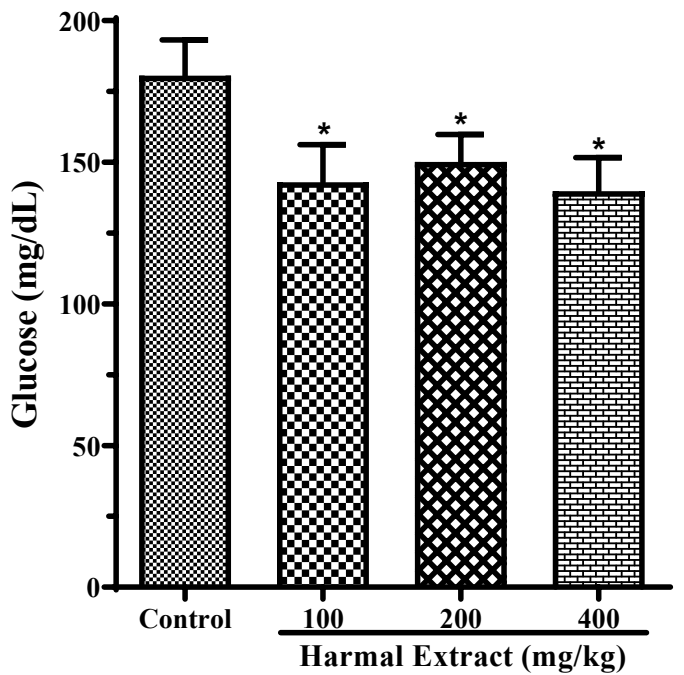

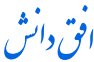

تصوير F. كلوكز سرم خون حيوانات در كروههاي مختلف آزمايش. كرومهاي

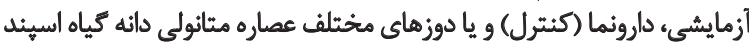

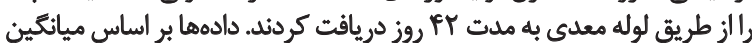

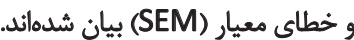

طور معنى دارى هايينتر از تروه كنترل بود (تصوير شماره V).

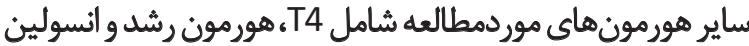
تفاوت معنى دارى نشان ندادند (جدول شماره باري ).

ثs?

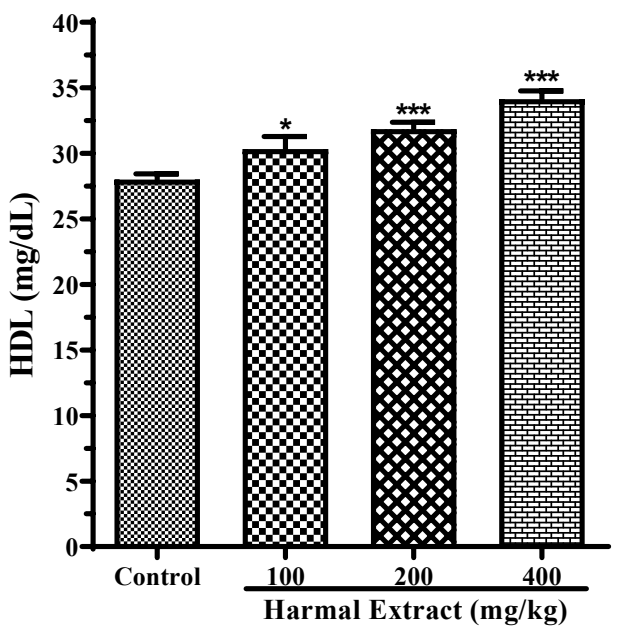

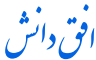

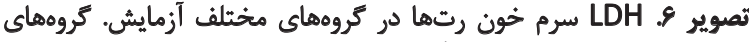

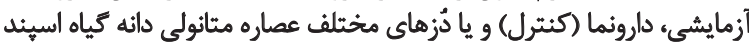

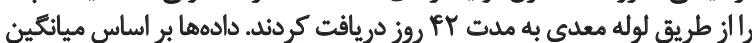

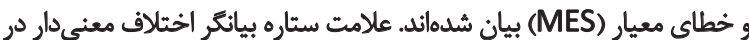

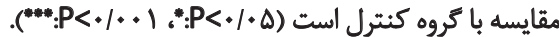

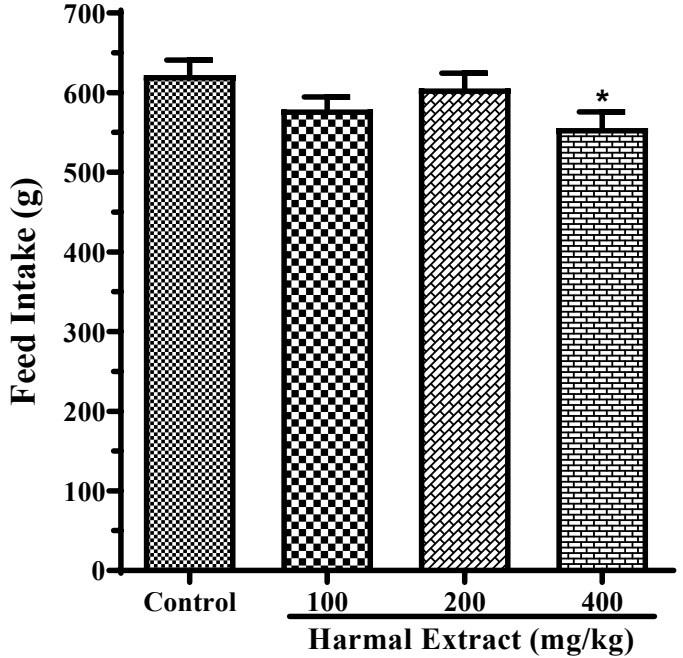

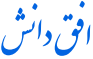

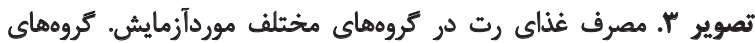

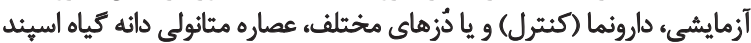

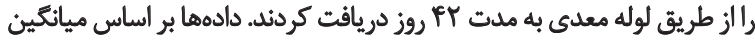

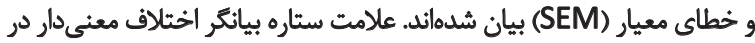

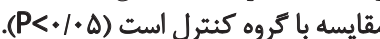

در ساير فراسنجهاي سرمى شامل ترى تليسيريد، LDL و يروتئين

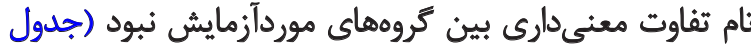

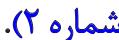

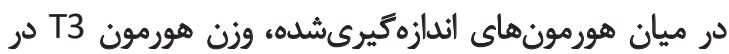

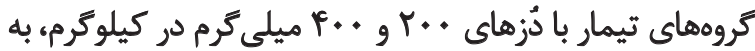

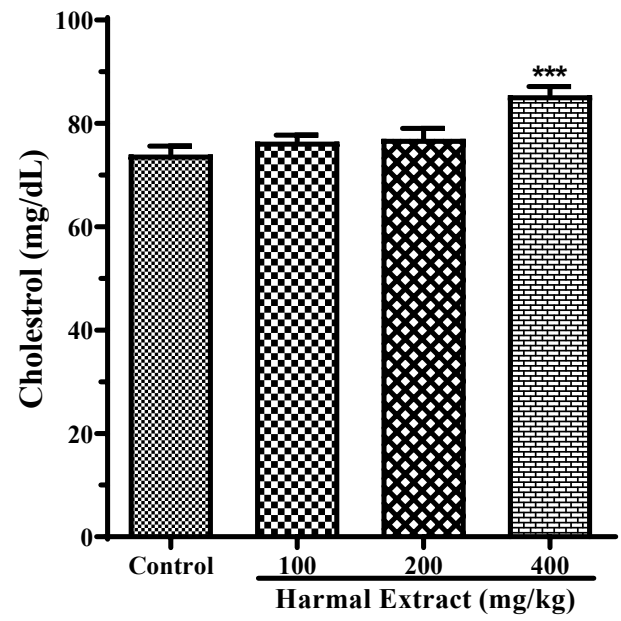

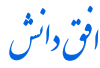

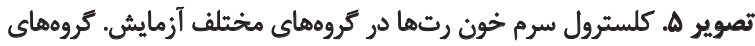

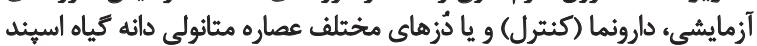

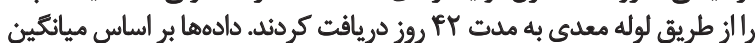

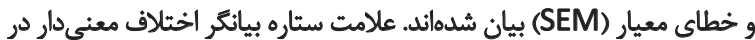

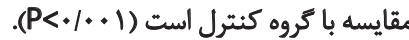


جدول r. يارامترهاي مورد مطالعه در كروههاي مختلف مورد آزمايش

\begin{tabular}{|c|c|c|c|c|}
\hline \multicolumn{4}{|c|}{ ميانكين 土|نحر اف معيار } & \multirow{3}{*}{ ثاراهتر/ تحووه } \\
\hline \multicolumn{3}{|c|}{ عصاره دانه اسيند (mg/kg) } & \multirow{2}{*}{ كتثرل } & \\
\hline$\varepsilon+4$ & $r+$ & $1+4$ & & \\
\hline$M / A \pm \Delta / \&$ & rqr $\pm \& / 1$ & $r \cdot / A \pm V /{ }^{\mu}$ & $19 / p \pm 1 / p$ & ضريب تبديل غنايي \\
\hline$\Delta / A \pm \cdot / 8$ & $8 / 1 \pm \cdot / 1$ & $g / A \pm \cdot / \Delta$ & $V / D \pm \cdot N$ & جربيى عضله (لرصل) \\
\hline $\mid r / q \pm \Psi \%$ & $\| W / Y \pm V / \Delta$ & $\| F / Y \pm W / N$ & $\mid Q / Y \pm 1 / r$ & مروتئين عضله (درصد) \\
\hline$|/ \Delta| \pm \cdot / T)$ & $|/ \& \& \pm \cdot / M|$ & $1 / P a \pm \cdot / r$ & $V / N= \pm / M V$ & خاكستر عضله (درصد) \\
\hline$M \cdot / A \pm \cdot / \Delta$ & $m / / e \pm / l$ & $m / T \pm \cdot 18$ & $M / r \pm \cdot N$ & ماده خشك عضله (درصد) \\
\hline$r / \Delta r \pm+/ * V$ & $r / \varphi \pm \pm \cdot / \cdot v$ & $r / f \Delta \pm . / \cdot q$ & $m / m v \pm . /$ & وزن كبد (درصد) \\
\hline$* / r+ \pm+/+r$ & $* / \mu \mid \pm * /+r$ & $+/ M \mid \pm+/+r$ & $+/ r q \pm+/+1$ & وزن طحال (درصد) \\
\hline$+/ \mu A+1+1$ & $\cdot / \mu \mid \pm \cdot / \Delta$ & $\bullet / \varphi \cdot \pm \bullet / \bullet r$ & $+/ r \varepsilon \pm \cdot / * 1$ & ونن قلب (درصد) \\
\hline$\Delta V / r \pm V / N$ & $\Delta H / F \pm T / \Delta$ & $\Delta H / \Delta \pm T / Q$ & $\Delta T / \Psi T M / /$ & ترى كليسيريد (mg/dL) \\
\hline$N \cdot \pm \cdot 10$ & $V M \pm .18$ & $N \cdot \pm \cdot / F$ & $N \& \pm .18$ & $\mathrm{LDL}(\mathrm{mg} / \mathrm{dL})$ \\
\hline $8 / N \pm . / K$ & $8 / \Delta \pm \cdot / r$ & $8 N \pm / r$ & $8 / P \pm / 1$ & ميروتئين تام (g/dL) \\
\hline$r / \pm \cdot /$ & $T / Y \pm \cdot / r$ & $r / T \pm \cdot / f$ & $r / r \pm \cdot r$ & $(\mu \mathrm{g} / \mathrm{dL}) \mathrm{Tr}$ \\
\hline$\cdot 1 \cdot 1 \pm \cdot 1 \cdot 1$ & $\cdot 1 \cdot A \pm * 1 * 1$ & $* \bullet 1 \pm *$ & $\cdot 1 \cdot \pm \cdot / \cdot r$ & هورمون رشد (ng/ml) \\
\hline $.1 .9 \pm .1 .0$ & $.1 .9 \pm . /$. & $\bullet / \cdot \pm * / *$ & $. / .9 \pm * /$. & 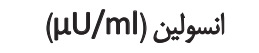 \\
\hline
\end{tabular}

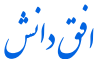

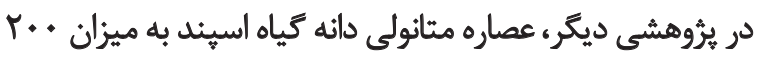

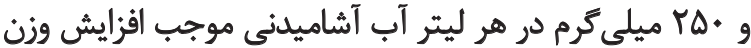

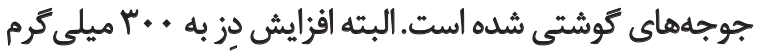

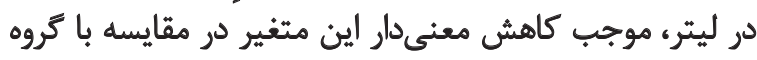

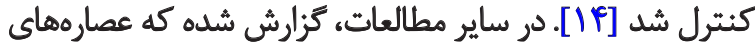

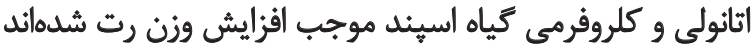

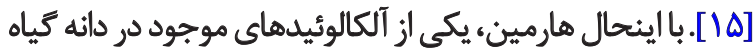

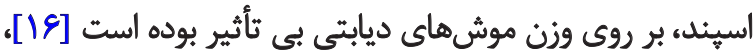

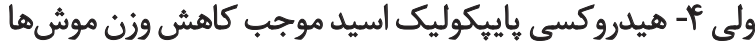

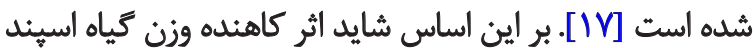

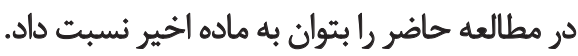

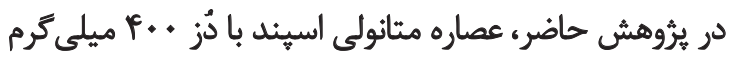

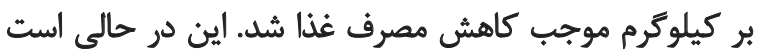

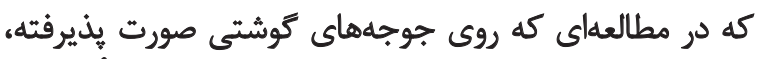

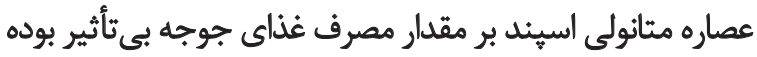

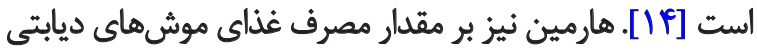

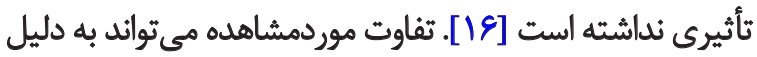

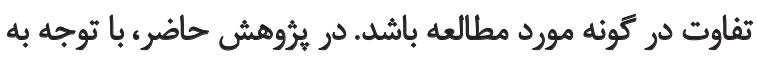

جاقي، نوعى بيمارى تغذيهاي است كه در ايجاد بسيارى از

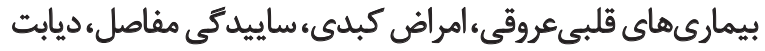

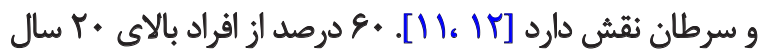

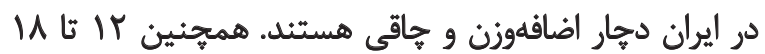

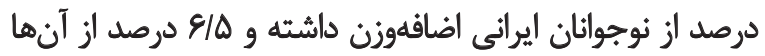

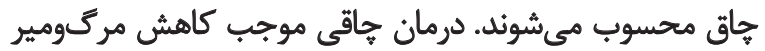

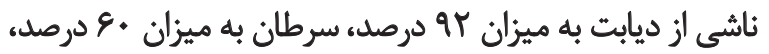

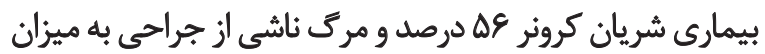

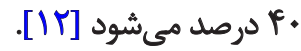

اين يثوهش، به بررسى ثأثير دانه كياه اسيند بر وزن و

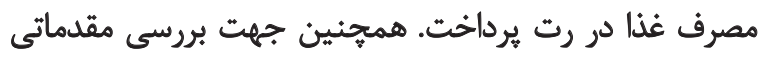

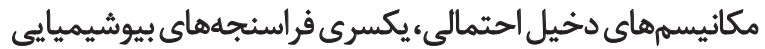
سرم نيز مورد مطالعه قرار كرفتند. در يُوهش حاضر، حيواناتى كه عصاره متانولى اسيند را با ذُز

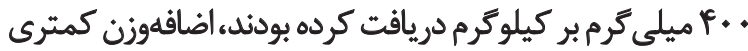

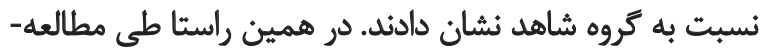

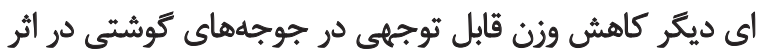

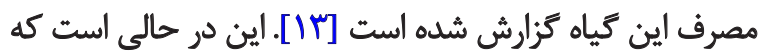


حيوانات مشاهده نشد. در مطالعات ساير محققين نشان داده شده

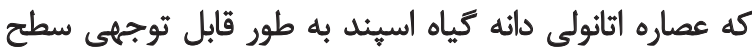

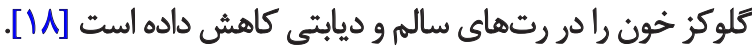

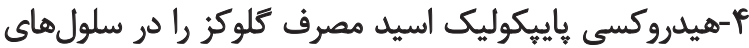

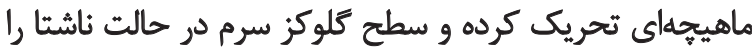

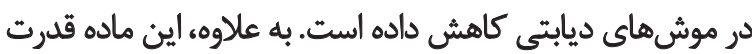

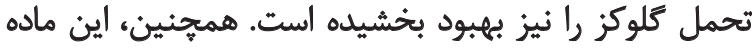

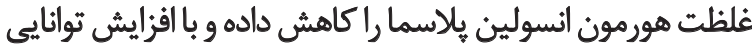

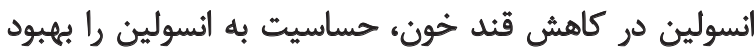

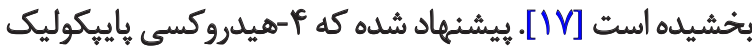

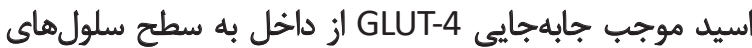
ماهيجه اسكلتى و در نتيجه افزايش مصرف كلوكز مئ مئشود

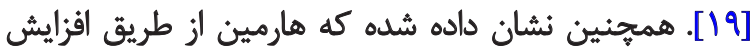

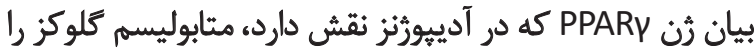

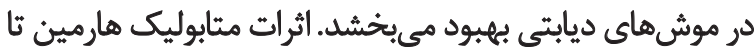

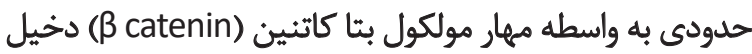

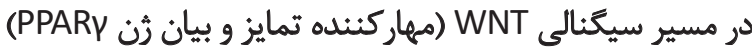

|ست[19].

از آنجا كه ميزان ترى كليسيريد سرم با اجاقى ارتباط مستقيم

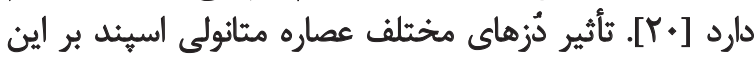

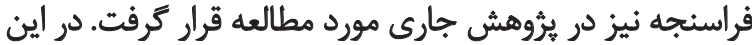

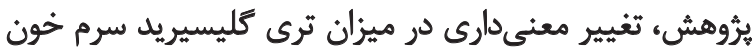

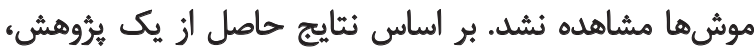

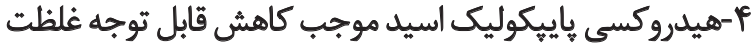

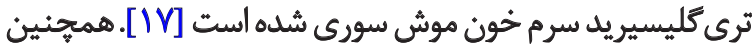

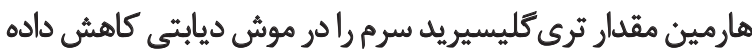

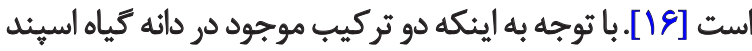

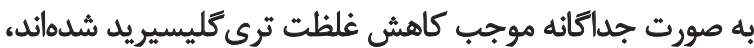

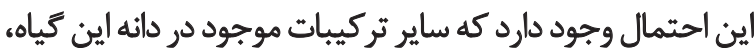

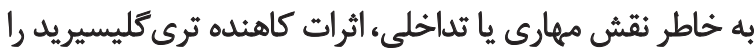
در يُؤهش جارى خنثى كرده باشند.

با توجه به همبستّى ميزان كلسترول سرم با متابوليسم بدن

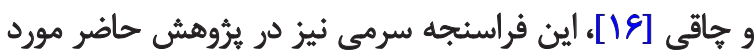

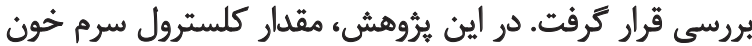

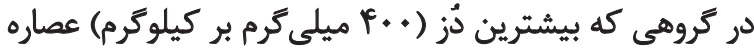

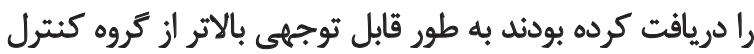

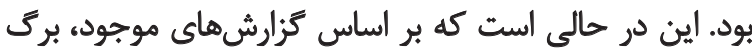

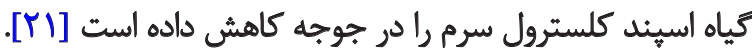

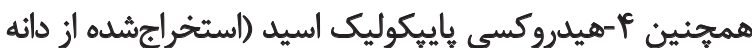

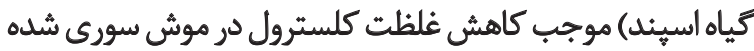

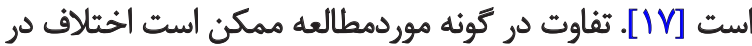

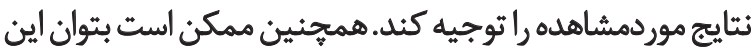
رخداد را به افزايش HDL و عدم تغيير LDL نسبت دمادين داد.

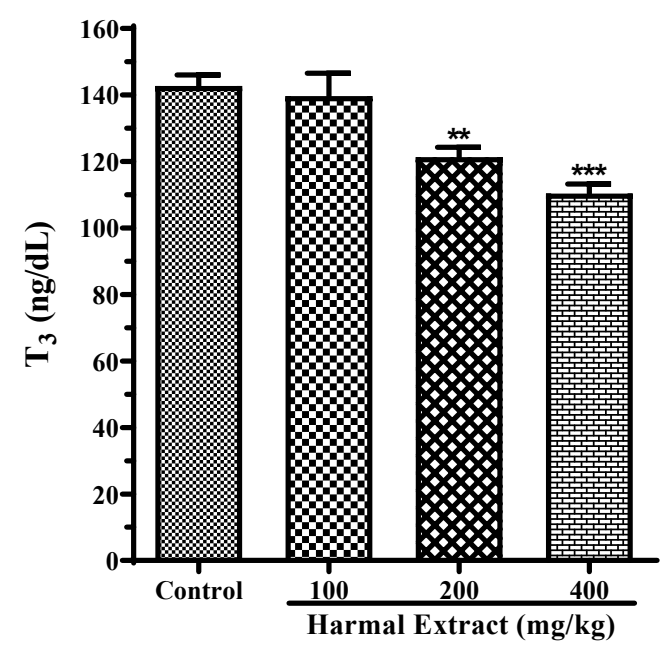

نُ

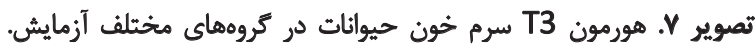

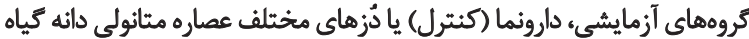

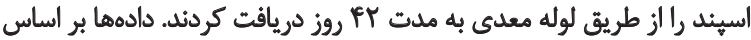

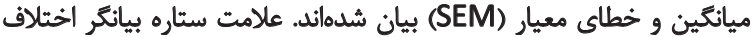

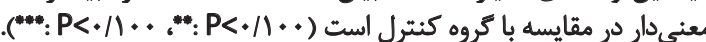

همخوانى كاهش مقدار مصرف غذا با ميزان اضافهوزن، به نظر

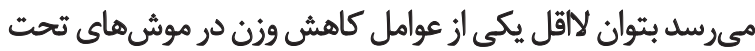

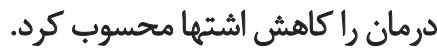

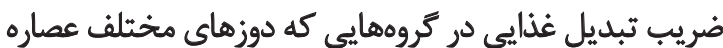

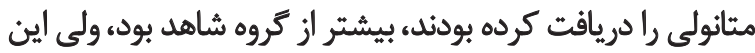

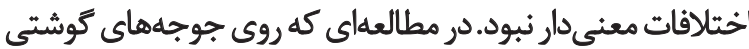

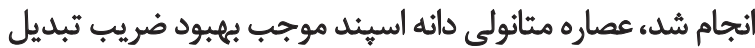

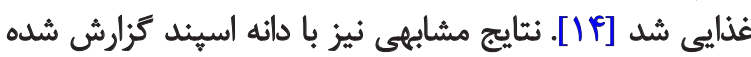

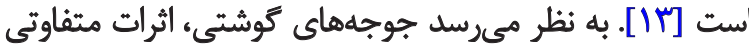

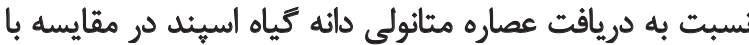

$$
\text { رت نشان مي دهئد. }
$$

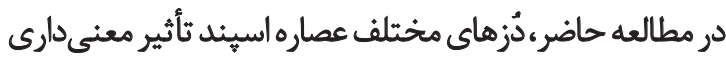

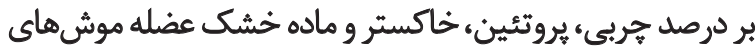

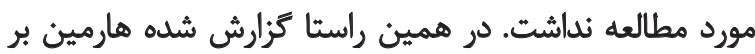

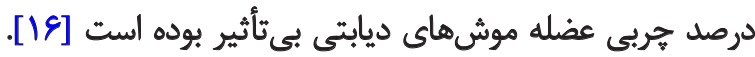

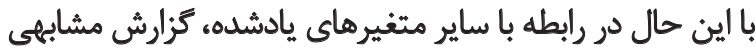
مشاهله نشئ.

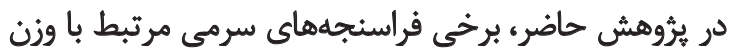

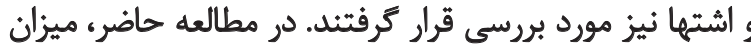

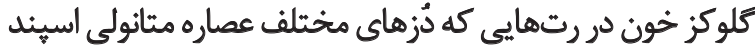

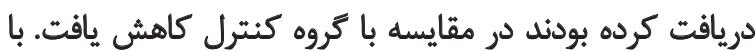

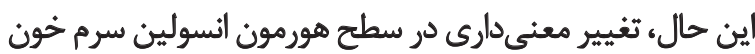


ميزان هورمون رشد سرم خون مشاهده نشد.

در يُروهش حاضر، ميانگين درصد وزن قلب مورد بررسى قرار

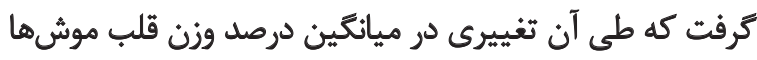

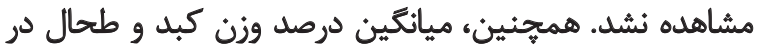

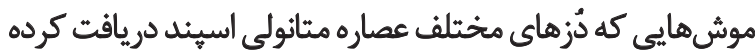

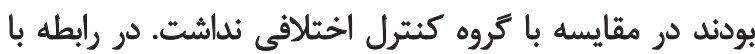

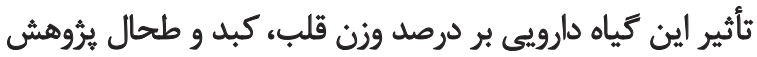

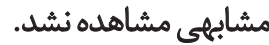

\section{تئيجليرى}

در ثروهش حاضر، تأثير ذُهاى مختلف عصاره مثانولى دانه

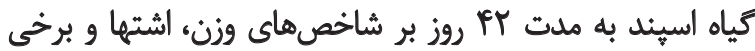

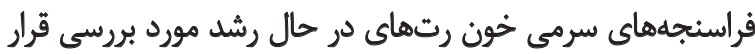

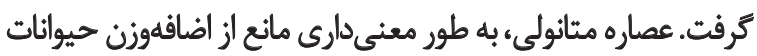

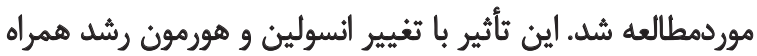

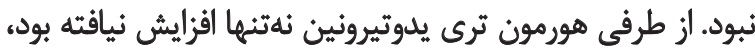

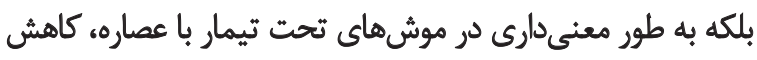

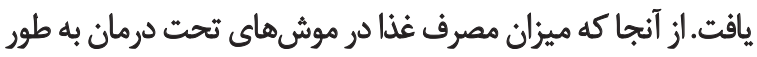

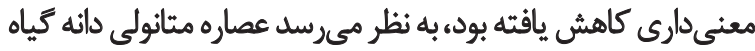

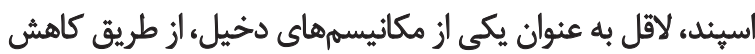

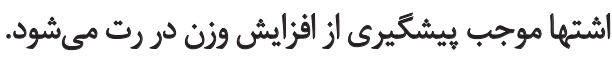

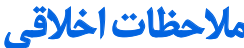 \\ يبروى أو اصول الخالاق بثروهش}

اين بثروهش بر اساس مقررات و قوانين كميثه اخلاق دانشعاه

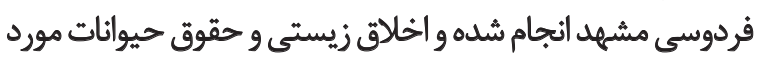
مطالعه لحاظ شده است (كد اخلاق: IR.UM.REC.1398.117).

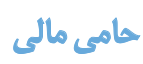

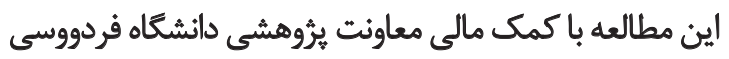

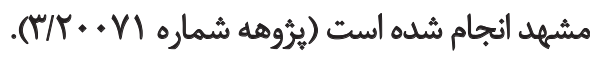

مشاركت ثويسند مكان

انجام آزمايشات ونغارش بيشنويس مقاله: اسماعيل ملاشاهي؛

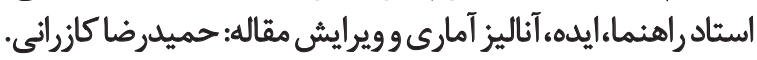

تعارض مناقع

هيجّونه تعارض منافع توسط نويسندكان بيان نشده است.

$$
\text { تشكر و قثدرواني }
$$

بدينوسيله از معاونت ثروهشى دانشَّاه فردوسى مشهد

$$
\text { قدردائى مىشود. }
$$

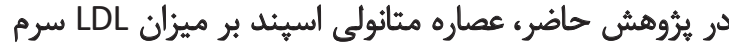

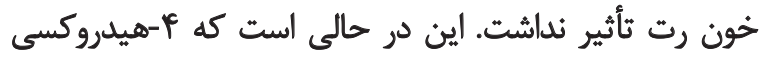

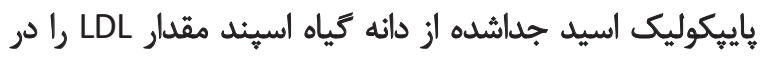

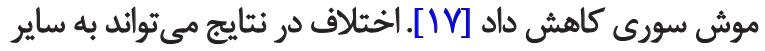

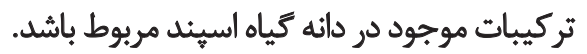
در اين يرؤهش، مقدار HDL سرم در كروهمايي كه عصاره

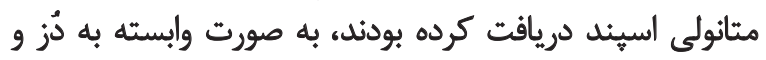

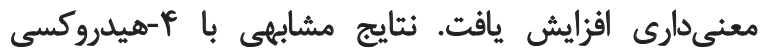

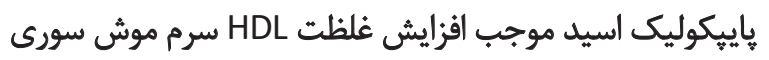

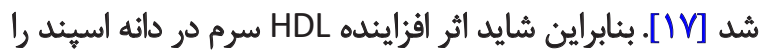

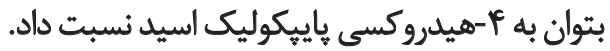

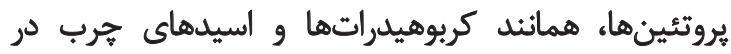

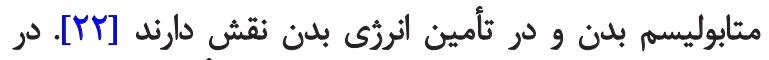

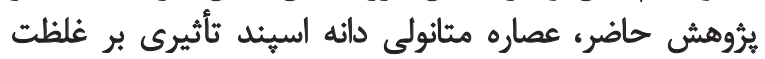

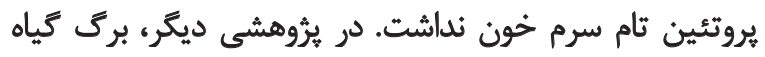

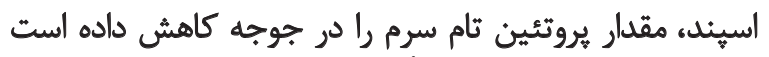

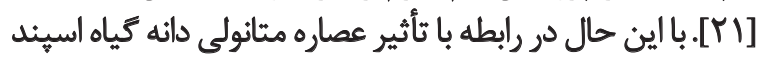

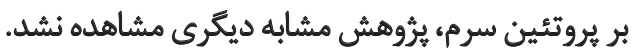

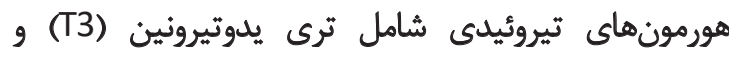

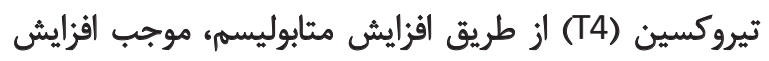

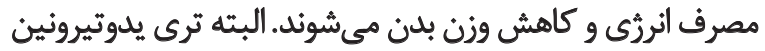

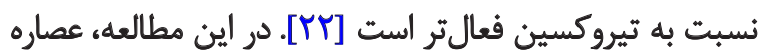

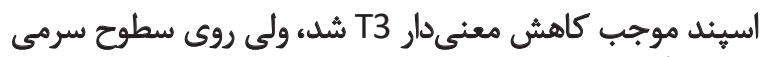

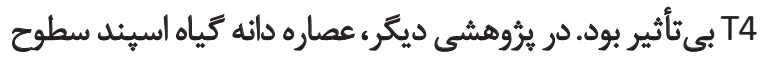

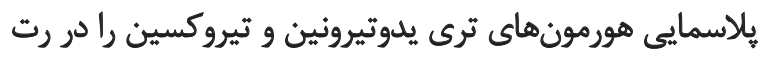

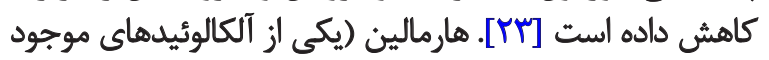

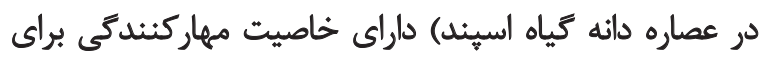

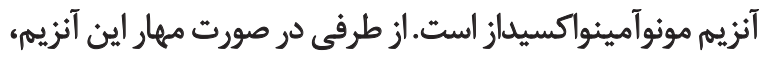

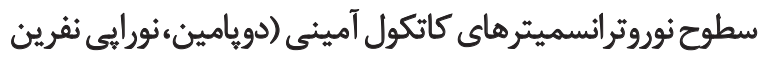

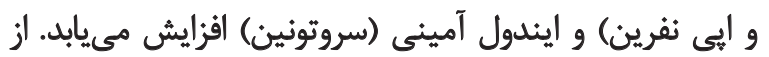

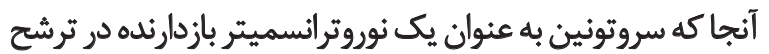

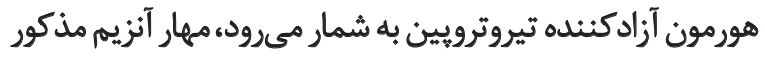

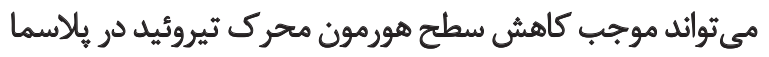

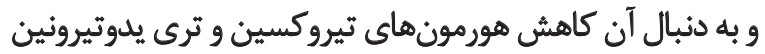

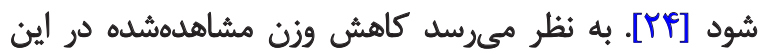

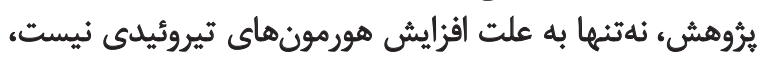

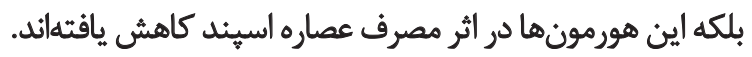
هورمون رشد، موجب افزايش رشد بافتهاى مختلف بلدن،

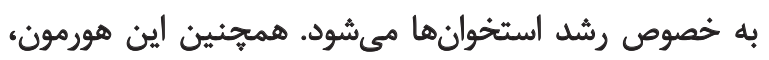

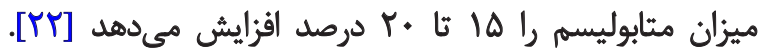

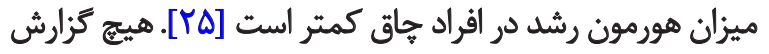

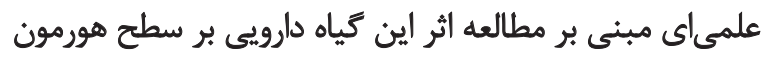

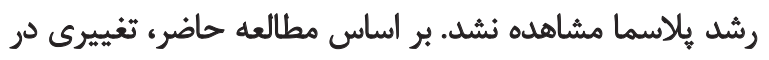




\section{References}

[1] World Health Organization. Obesity and overweight [Internet]. 2020. [Updated 2020 Apr 1]. Available https://www.who.int/news-room/factsheets/detail/obesity-and-overweight

[2] Segula D. Complications of obesity in adults: A short review of the literature. Malawi Medical Journal. 2014; 26(1):20-4. [PMID] [PMCID]

[3] Mirheydar H. Maaref Giahi (Plant Knowledge). $2^{\text {nd }}$ ed. Tehran: Daftare Nashre Farhange Eslami; 1996. http://opac.nlai.ir/opac-prod/bibliographic/512477

[4] Zargari A. [Medicinal plants (Persian)]. $6^{\text {th }}$ ed. Tehran: Tehran University Press; 1996. http://opac.nlai.ir/opac-prod/bibliographic/494792

[5] Pooyan M. Medicinal plants of Southern Khorasan (Persian). Mashhad: Danesh-Pooyesh; 1989.

[6] Salehi Yeganeh Rad F. [Medicinal plants in the North of Khorasan (Persian)]. Mashhad: Department of Environment; 2001. http://opac.nlai.ir/ opac-prod/bibliographic/618748

[7] Samsam Shariat H, Moattar F. [Traditional pharmacy (Persian)]. $2^{\text {nd }}$ ed. Tehran: Rozbahan; 1990. http://opac.nlai.ir/opac-prod/bibliographic/718659

[8] Saleh F, Tahir M, Ohtsuka A, Hayashi K. A mixture of pure cellulase, hemicellulase and pectinase improves broiler performance. British Poultry Science. 2005; 46(5):602-6. [DOI:10.1080/00071660500255661] [PMID]

[9] Nafikov RA, Ametaj BN, Bobe G, Koehler KJ, Young GW, Beitz DC. Prevention of fatty liver in transition dairy cows by subcutaneous injection of glucagon. Journal of Dairy Science. 2006; 89(5):1533-45. [DOI:10.3168/ jds.S0022-0302(06)72221-4]

[10] Hosseini Z. [Common methods for food analysis (Persian)]. $6^{\text {th }}$ ed. Shiraz: Shiraz University Press; 2007. http://opac.nlai.ir/opac-prod/bibliographic/565308

[11] Saremi A, Khamsei A, Ervin Daniel J. [Obesity causes (Persian)]. Tehran: Tchehr; 1991. http://opac.nlai.ir/opac-prod/bibliographic/557561

[12] De-Silva A, Bloom SR. Gut hormones and appetite control: A focus on PYY and GLP-1 as therapeutic targets in obesity. Gut Liver. 2012; 6(1):10-20. [DOI:10.5009/gnl.2012.6.1.10] [PMID]

[13] Bashar YA, Abubakar A. Performance of broiler birds fed pumpkin (Cucubita maxima) seed meal. Proceeding of the $26^{\text {th }}$ Annual Confe of NSAP. 2001; 26:283-5.

[14] Tanweer AJ, Chand N, Khan S, Qureshi MS, Akhtar A, Niamatullah M. Impact of methanolic extract of peganum harmal on the weight gain, feed conversion ratio, feed cost and gross return of broiler chicks. The Journal of Animal \& Plant Sciences. 2012; 22(2):264-7. http://www.thejaps.org.pk/docs/v-22-2/04.pdf

[15] Nworgu FC. Economics of utilization of cocoa (Theobroma cacao) pod husk meal by cockerel chicks. Moor Journal of Agricultural Research. 2002; 3(2):217-22.

[16] Waki H, Park KW, Mitro N, Pei L, Damoiseaux R, Wilpitz DC, et al. The small molecule harmine is an antidiabetic cell-type-specific regulator of PPARgamma expression. Cell Metabolism. 2007; 5(5):357-70. [DOI:10.1016/j.cmet.2007.03.010] [PMID]

[17] Singh AB, Khaliq T, Chaturvedi JP, Narender T, Srivastava AK. Anti-diabetic and anti-oxidative effects of 4-hydroxypipecolic acid in C57BL/ KsJ-db/db mice. Human \& Experimental Toxicology. 2012; 31(1):57-65. [DOI:10.1177/0960327111407227] [PMID]
[18] Singh AB, Chaturvedi JP, Narender T, Srivastava AK. Preliminary studies on the hypoglycemic effect of Peganum harmal L. Seeds ethanol extract on normal and streptozotocin induced diabetic rats. Indian Journal of Clinical Biochemistry. 2008; 23(4):391-3. [DOI:10.1007/s12291-0080086-3] [PMID] [PMCID]

[19] Naresh G, Jaiswal N, Sukanya P, Srivastava AK, Tamrakar AK, Narender T. Glucose uptake stimulatory effect of 4-hydroxypipecolic acid by increased GLUT4 translocation in skeletal muscle cells. Bioorganic \& Medicinal Chemistry Letters. 2012; 22(17):5648-51. [DOI:10.1016/j. bmcl.2012.06.101] [PMID]

[20] Amir Rasouli H. [Clinical biochemistry (Persian)]. Tehran: Jafari and Azar; 1991. http://opac.nlai.ir/opac-prod/bibliographic/506080

[21] Qazan WS. The effect of low Levels of dietary Peganum harmal L. and Ballota undulate or their mixture on chicks. Journal of Animal and Veterinary Advances. 2009; 8(8):1535-8. [DOI:javaa.2009.1535.1538]

[22] Hall JE, Guyton AC. Guyton and Hall textbook of medical physiology. Philadelphia: Elsevier Saunders; 2011. https://books.google.com/ books?id=di5PtQAACAAJ\&dq

[23] Hossini E, Sadeghi H, Daneshi A. [Evaluation of hydro-alcoholic extract of Peganum harmal on pituitary-thyroid hormones in adult male rats (Persian)]. Armaghane Danesh. 2009; 14(4): 23-30. http://armaghanj. yums.ac.ir/article-1-579-en.html

[24] Monsef HR, Ghobadi A, Iranshahi M, Abdollahi M. Antinociceptive effects of Peganum harmal L. alkaloid extract on mouse formalin test. Journal of Pharmacy \& Pharmaceutical Sciences. 2004; 7(1):65-9. [PMID]

[25] Beck P, Koumans JHT, Winterling CA, Stein MF, Daughaday WH, Kipnis DM. Studies of insulin and growth hormone secretion in human obesity. The Journal of Laboratory and Clinical Medicine. 1964; 64(4):654-67. [DOI:10.5555/uri:pii:0022214364900332] 
This Page Intentionally Left Blank 